\title{
虚血性心疾患をともなった肝臟癌症例に対する 心肝同時手術の 1 治験例
}

\begin{tabular}{|c|c|c|c|c|c|}
\hline \multicolumn{6}{|c|}{ 岐阜大学第 1 外科 } \\
\hline 飯田 & 辰美 & 伊藤 & 英夫 & 片桐 & 義文 \\
\hline 荒川 & 博徳 & 宮田 & 知幸 & 酒井 & 盍 \\
\hline 千賀 & 省始 & 林 & 勝知 & 広瀬 & \\
\hline
\end{tabular}

症例は68歳の男性で, 手術適応のある冠動脈狭窄を伴った肝細胞癌症例に対し，1期的に冠動脈再 建術と肝切除術を施行した。

冠動脈病変は右冠動脈の完全閉塞, 左主幹動脈, 左回旋枝のいずれるで75\%狭窄が存在し, 肝葴の 病変は後下区域に径 $30 \mathrm{~mm}$ 大の肝細胞癌が認められた。術前の心機能は駆出率 0.65 と良好で, かつ臨 床病期 I と肝予備能も十分であった。まず体外循環下に 3 枝に大動脈一冠動脈バイパス術を行い，術 中の心係数も $3.21 / \mathrm{kg} / \mathrm{m}^{2}$ と良好で, activated coagulation time (ACT) む144秒と血液凝固能も安 定していた。 よって体外循環離脱後, 引き続き肝後下亜区域切除術を施行した。術中術後経過は良好 で, 管理困難な出血, 創感染などはなく, 術後10か月の現在, 肝細胞癌の再発なく健在である.

このことは今後增加するであろう虚血性心疾患を合併した肝細胞癌に対する積極的な治療法の 1 選 択肢を示唆するものである。

Key words: hepatocellular carcinoma combined with ischemic heart disease, simultaneous operation

はじめに

近年, 高齢者の増加に伴い, 虚血性心疾患と腹部悪 性腫湯の併存例も増加している12).

外科的再建の必要な冠動脈病変と切除可能な肝臟癌 を有する症例に 1 期的に冠動脈再建術 (coronary artery bypass grafting；以下 CABG）之肝亜区城切 除術を行い，良好な結果を得たので報告する。

\section{症例}

患者：68歳, 男性

主訴：下腹部痛

家族歴：父が糖尿病, 脳梗塞で78歳時死亡. 母が胃 癌で67歳時死亡.

既往歴：31歳時虫垂炎で虫垂切除術.60歳時より肝 機能異常を指摘されていたがとくに治療はなされてい ない. 66歳時肺资で 1 か月間入院治療. 67歳時前立腺 肥大症で経尿道的前立腺切除。

現病歴：1991年12月右下腹部痛があり近医を受診 し, 精查のため入院となった。諸検査の結果, 肝腫瘤,

$<1993$ 年 2 月 10 日受理 $>$ 別刷請求先：飯田 辰美

厂500 岐阜市司町40 岐阜大学医学部第 1 外科
腹部大動脈瘤，結腸ポリープ，糖尿病と診断され，結 腸ポリペクトミーの後肝腫瘤の治療のため1992年 2 月 に当科へ紹介入院となった.

入院時現症：体格中等, 栄養良. 脈拍 $84 /$ 分で整, 血 圧138/90mmHg であった。結膜に貧血黄疸はなく，胸 部にる打聴診上特記すべき所見はなかった。腹部では 肝脾は触知せず，湾左側で無痛性の拍動性腫瘤を触知 したが，血管性雑音は聴取しなかった。

血液生化学的検查成績: WBC $7,200 / \mathrm{mm}^{3}, \mathrm{RBC}$ $542 \times 10^{4} / \mathrm{mm}^{3}$, ヘモグロビン $17.2 \mathrm{~g} / \mathrm{dl}$, へマトクリッ

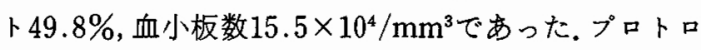
ンビン時間 $100 \%$ ，トロンボテスト $89 \%$, activated coagulation time (ACT) 111秒々血液凝固能孔正常で あった。

総蛋白 $7.6 \mathrm{~g} / \mathrm{d} l$, アルブミン $4.0 \mathrm{~g} / \mathrm{d} l, N a 143 \mathrm{mEq} /$ $l, \mathrm{~K} 4.5 \mathrm{mEq} / \mathrm{l}, \mathrm{Cl} 104 \mathrm{mEq} / \mathrm{l}, \mathrm{BUN} 10.0 \mathrm{mg} / \mathrm{dl}$, Creatinin $0.8 \mathrm{mg} / \mathrm{ml}$, 総ビリルビン $0.7 \mathrm{mg} / \mathrm{ml}$, GOT 22U, GPT 35U, LDH 277U, ChE 1.07U/L, $\gamma$-GTP $22 \mathrm{U}$, 総コレステロール $227 \mathrm{mg} / \mathrm{dl}$, トリグリセライド $135 \mathrm{mg} / \mathrm{dl}$, CPK 67U, CRP 0.22で異常值はなかった. 腫煌マーカーは carcinoembryonic antigen(以下 
CEA) $5.7 \mathrm{ng} / \mathrm{ml}$ とやや高値で, $\alpha$-fetoprotein（以下 AFP) $358 \mathrm{pg} / \mathrm{ml}$ と高值であった。

Indocyanine green (以下 ICG) 15 分停滞率 $21 \%, \mathrm{~K}$ 值0.101であり, 肝予備能の低下が認められた。 Hepati. tis $\mathrm{C}$ virus (以下 $\mathrm{HCV}$ ) 抗体陽性, hepatitis B (以 下 HB）抗原抗体陰性であった。

また検尿にて糖，蛋白は陰性で，クレアチニンクリ アランスも $83 \mathrm{ml} /$ 分と良好であった。

胸腹部単純 $\mathrm{X}$ 線像：特記すべき所見は認められな かった。

心電図所見：安静時心電図では洞整脈，94/分で $\mathrm{ST}, \mathrm{T}$ の変化はなかった。経食道心房ペーシング3)に よる負荷心電図では $V_{2,3,4}$ でST の低下が認められた。 心蔵超音波検查所見：心臓壁，3弁の動きには異常 なく，EDVI $68.4 \mathrm{ml} / \mathrm{m}^{2} ， \mathrm{EF} 0.65$ と良好であった。

腹部超音波検査所見：肝後下区域に径 $2.5 \mathrm{~cm}$ 大で

Fig. 1 (upper) Computed tomograrhy after lipiodol injection revealed high density region in the posterior segment of the liver. (under) $\mathrm{He}$ patic arteriography also revealed tumor stain in the liver.
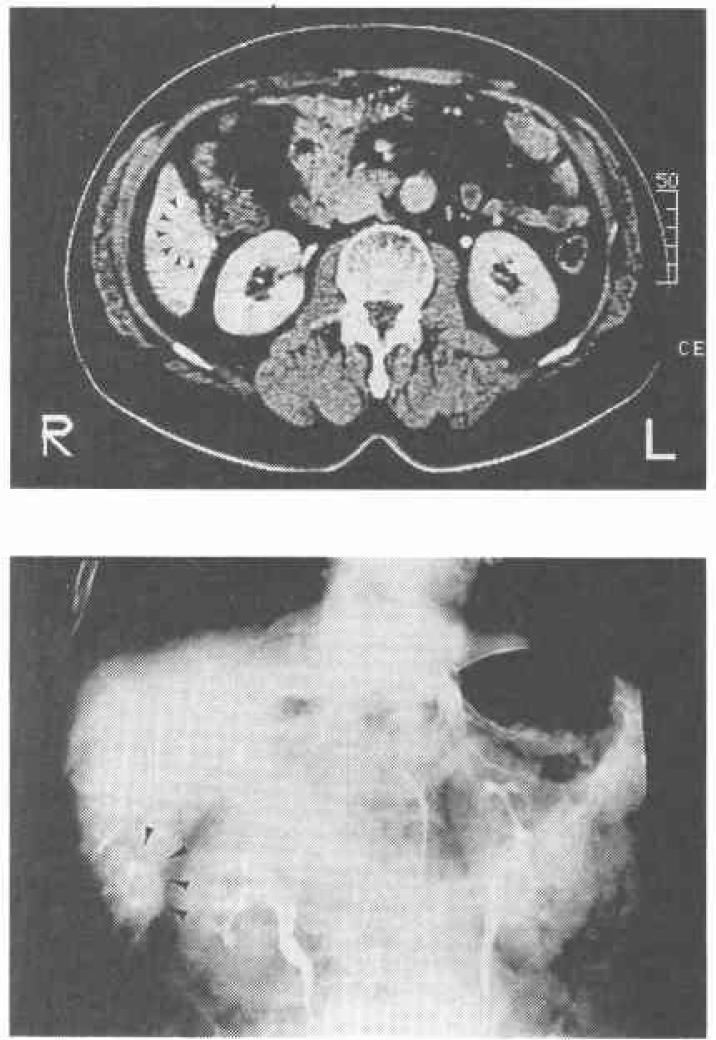

辺縁不整なやや低エコーな腫瘤影が認められ，胠左側 で最大径 $4.0 \mathrm{~cm}$ の動脈瘤と思われる拍動性の低工 コー域が認められた。

腹部 CT 検查所見：肝後下区域に $2.5 \times 2.5 \mathrm{~cm}$ の境 界不鮮明な low density area があり, 造影 CT でより 不鮮明となった。リピオドール注入後 3 週間目では, 後下区域の low density areaの外縁に high density な集積が認められた。また腹部大動脈は腎動脈分枝部 より $3.0 \mathrm{~cm}$ 末梢から拡張があり最大径 $4.0 \mathrm{~cm}$ であっ た (Fig. 1).

心血管造影所見：左冠動脈主幹部の75\%狭窄之右冠 動脈中权側の完全閉塞が認められた。なお左前下行枝 から側副血行を介し右冠動脈が造影されていた。いわ ゆる jeopardized collateral であった。左室造影から の EFは0.65であった（Fig. 2).

腹部血管造影所見：肝動脈造影では静脈相で後下区 域に不整形の腫演濃染像があり，上腸間膜動脈造影静 脈相では門脈の腫煬塞栓は認められなかった（Fig. 1).

Fig. 2 Coronary arteriography shows obstruction of right coronary artery, stenosis of left main trunk and also shows jeopardized collateral.
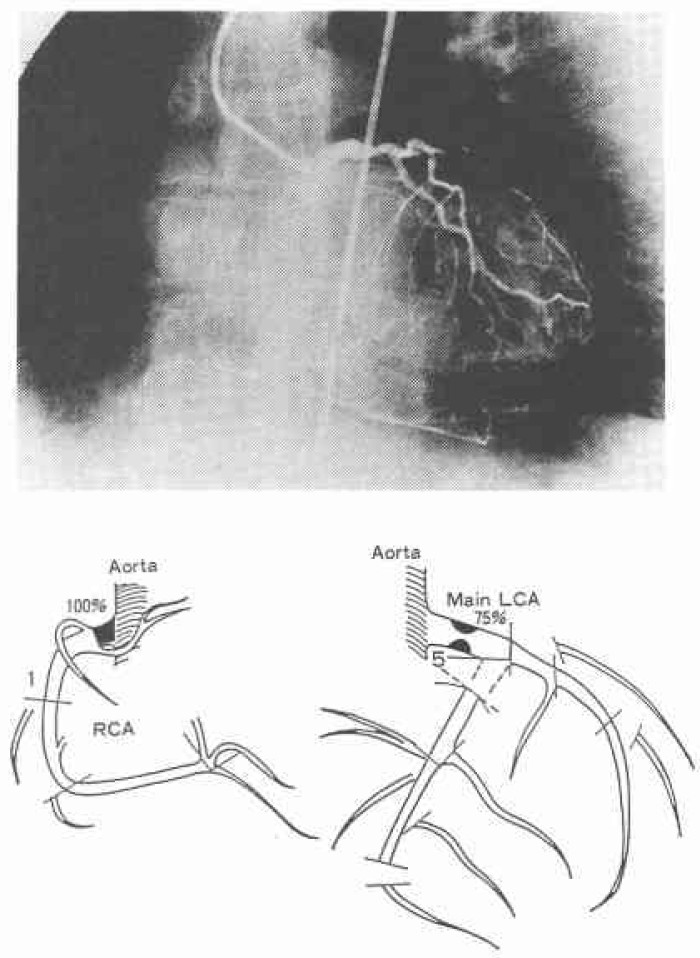
以上の検査所見より，手術適応のある狭心症と肝細 胞癌と診断された，大動脈瘤は搪張が軽度であり壁在 血栓もないため経過観察とした。肝悪性腫湟切除とそ れに伴う心合併症の危険を考慮し，心肝 1 期的手術を 施行することとした。

手術所見および術中経過：1992年 3 月17日胸骨正中 切開から体外循環下に右冠動脈, 左前下行枝, 左回旋 枝の 3 枝にCABGを施行した。体外循環時間130分， 大動脈遮断時間56分であった。体外循環のために使用 した HeparinにてACT は延長していたが，体外循環 終了時硫酸プロタミン投与により ACT は144秒と回 復した。胸部操作終了時 Dopamine $2 \mu \mathrm{g} / \mathrm{kg} / \mathrm{min}$. 投 与下で血压 $120 / 70 \mathrm{mmHg}$ と安定しており, また心係数 む $3.2 \mathrm{l} / \mathrm{min} / \mathrm{m}^{2}$ と良好であった。

胸骨閉鎖により 70 分後, 肋骨弓下切開により開腹し た.腹部大動脈は腎動脈分枝部より約 $4 \mathrm{~cm}$ 末梢し軽度 紡錘状に拡張し，壁硬化が著明であった。

肝蔵は辺縁はやや鈍であるが軟らかく術中超音波で 後下区域に不整形の腫瘤を認めた。間歇的片葉阻血下 に後下亜区域切除術を行った，肝切除術中の出血量は $1,300 \mathrm{ml}$ とやや多かったが肝静脈の損傷によるもの で，断端止血に難渋することはなかった。腹部手術時 間は250分であった，総麻酔時間12時間15分, 総手術時 間9時間 40 分, 総出血量 $1,400 \mathrm{ml}$, 総輸血量 $2,400 \mathrm{ml}$ で あった。
Fig. 3 (upper) Resected specimen shows that tumor consists of multiple nodules. (under) Microscopic view shows HCC (Edmondson grade III) (Hematoxillin-Eosin stain $\times 100)$.


Fig. 4 Mediansternotomy and subcostal abdominal incision were done. Single mediastinal drainage tube inserted in the left side of xyphoid process.
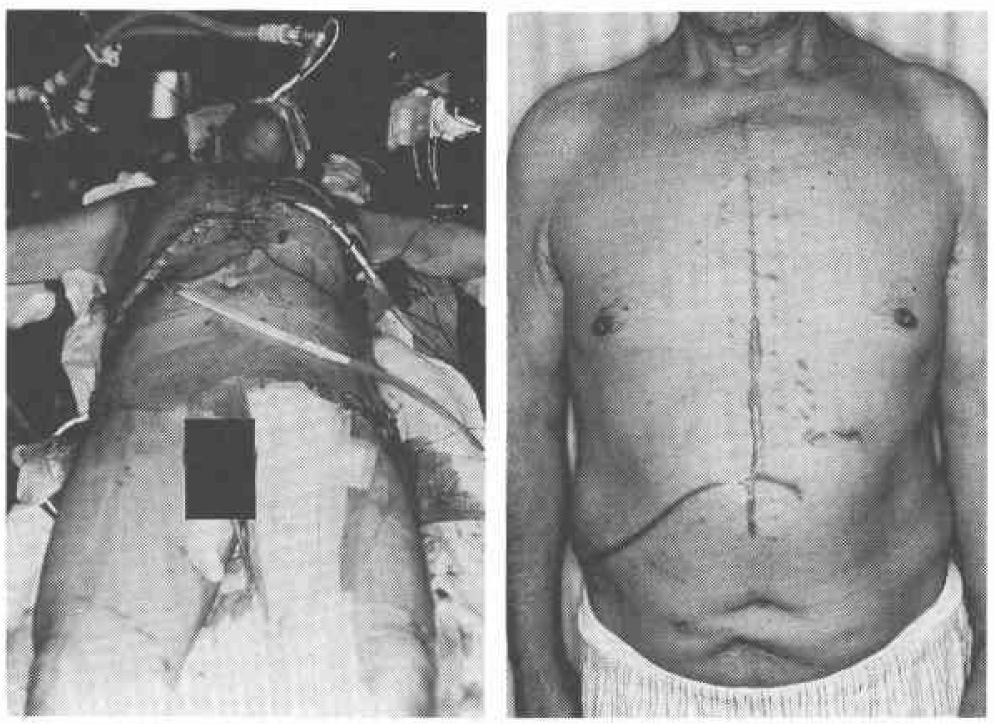
切除肝腫瘍は Edmondson grade III の肝細胞癌で 多結節癒合型 $2.5 \times 2.5 \times 2.0 \mathrm{~cm}$ であり, 占居部位 $\mathrm{P}$, $\mathrm{S}_{t}$, 大きさ $\mathrm{H}_{\mathrm{s}}$, 発育様式 $\mathrm{Eg}, \mathrm{Fc}(+), \mathrm{Fc}-\operatorname{Inf}(-)$, $\mathrm{Sf}(+)$ で, $\mathrm{S}_{0}, \mathrm{~N}(-), \mathrm{Vp}_{0} \mathrm{Vv}_{0}, \mathrm{~B}_{0}, \mathrm{IM}_{0}, \mathrm{P}_{0}, \mathrm{TW}$ (一)， $Z_{1}$ であった。 よって肉眼的進行程度は $\mathrm{T}_{2}, \mathrm{~N}_{0}$ ， $\mathrm{M}_{0}$, Stage II であり, HrS (P) の切除により相対的 治瘾切除であった（Fig. 3).

術後経過は良好で第21病日軽快退院した。

\section{考察}

虚血性心疾患に対する外科治療法ならびに肝細胞癌 に対する外科治療法はほぼ確立されており, 各疾患単 独に存在する場合には問題は少ない。しかし高齢者の 増加に伴い動脈硬化に起因する心血管疾患之悪性腫瘍 との併存例は当然増加するものと思われ，その際には その予後に最も貢献できる方法を選択しなければなら ない.このような心血管疾患之悪性腫瘍併存例に対し， 広瀬ら CABG を先行させ，その多くを約 1 か月後に悪性腫湯 切除との方針を示した.さらに同施設から ${ }^{2)}$, その経験 を生かして 1 期的手術の報告すある. 磯村ら”は1期 的手術の 5 例のらち開腹術は 2 例であるが良好な結果 を得たとしている. 志能ら ${ }^{5)}$, 岩本ら ${ }^{6)}$, 堀内ら $ら^{87}$, Dalton $5^{91}$ は心疾患併存腹部疾患に対する周術 期管理の特徵と percutaneous transluminal coronary angioplasty (PTCA), intra-aortic baloon puming （IABP）の有用性などを報告している.

本例では虚血性心疾患に対しては, 左冠動脈主幹部 狭窄と右冠動脈完全閉塞のため腹部手術前に冠血行再 建は必要であり, PTCA 適応外で CABG の適応であ ると判断した。ささらには術前の左心収縮能が良好で CABG 後の心機能も良好であろらと判断した.

また鬼束ら ${ }^{11}$ の報告から当教室の肝細胞癌に対する 治療では 5 年生存率からみて肝畽瘍切除例が最も成績 が良好で, 肝動脈塞栓術, エタノール注入寮法, 全身 化学療法などにも優れていた。このことから肝腫䁑に 対しても切除術の適応があると考えられた。

本例の上5に虚血性心疾患儿悪性腫婸が併存してい た場合, 両疾患に対する治療法, 両治療を行ら時期, 麻酔に伴 $5 \mathrm{Risk}^{10)}$, 胸部腹部切開創やドレーンの近接 による創感染症などに配虑が必要となる。

手術時期については肝切除の麻醉時の Risk 考兄 ると CABGを優先すべきと考点られる。しかし冠血行 再建が可能で，左室收縮力が良好であるという条件を 有する時, 悪性腫場の進行, 開心術後の全身状態, 免
疫能の回復などを考慮すると $\mathrm{CABG}$ と肝切除までの 間隔をいかにするべきかが問題となる，腹部病変が悪 性腫瑒であり，機能障害が高度であれば両手術の時間 的間隔はより短いことが望ましい，虚血性心疾患を重 視するあまり悪性腫瘍に対する手術時期を失し根治度 を下げたり，悪性腫湯を重視するあまり虚血性心疾患 に対する処置が不十分になることは回避するべきと考 光，本例を 1 期的手術とした。

本例では術前術中の心機能が比較的良好で術後に IABP を使用する可能性は少なく, 日本肝癌研究会 ${ }^{12)}$ による肝蔵の臨床病期 Iであることから肝予備能は十 分と考えられた。 また亜区域切除で相対的治癁切除が 得られる点を考慮して同時手術とした。

切開創は本症例では胸骨綎切開と肋骨弓下切開が連 続してしまったが，創治瘁，創感染を考虑すれば，可 及的に分割することが望ましい，腹部切開時には胸部 創は創被覆を行っておくべきで，本例でもそのように 行い創感染は生じなかった。 また心襄ドレーンは通常 2 本で上腹部左右に誘導しているが，今回は肝切除時 の切開, 腹部操作を考虑して1本でかつできうるかぎ り左上腹部より誘導した (Fig. 3).

今後の問題点として，心手術を先行させる 2 期的手 術を行うとすれば腫煌の進行速度, 転移の時期, 宿主 の免疫能の回復時期, 栄養評価などを考虑したうえで, 第 2 の手術を何時行らかが問題となる。一般的には約 1 か月としている施設がある。逆に 1 期的手術におい ては同時手術の手術侵襲を評価しうるなんらかの方法 が必要と考学られる、すなわちこのよらな症例の手術 法・手術時期の選択基準の設定が必要で, 臟器別の診 療体系を超えた検討が望まれる。

われわれが検索しえた範囲では心肝同時手術例の報 告はなかった.

本稿の内容の一部は第54回日本臨床外科医学会総会 （1992年11月，東京）シンポジウムにて発表した。 .

\section{文献}

1）広瀬 一, 谷口和博, 中埜 肃ほか：後天性心疾患 の外科に扰ける最近の問題点. 日外会誌 86 ： 1208-1211, 1985


悪性腫瘍合併症例に対する外科治療。日外会誌 $90: 2037-2043,1989$

3）東健一郎, 松本興治, 梅田正五はか：経食道心房 ベーシンズ負荷法による虚血性心疾患のスクリー ニングについて。脈管学 $30: 125-127,1990$

4）磯村 正, 久富光一, 古賀正之ほか：冠動脈バイパ 
ス術と非心葴疾患に対する合併手術の検討。日外 会誌 $92 ： 847-851,1991$

5）志熊 車, 武内敦郎, 佐々木進次郎ほか：悪性腫場 と虚血性心疾患に対する同時期手術. 胸部外科 $38: 518-523,1985$

6）岩本広二, 酒井克治, 木下博明ほか：悪性腫瘍を併 存した心疾患の手術適応。日胸外会誌 49 ： 1939-1944, 1988

7）堀内哲也, 井隼彰夫, 谷川充彦はか：心疾患を合併 した胃癌手術について.外科 $52: 274-278,1990$

8）小林 慎, 橘 正人, 公平一彦ほか：重篤な冠動脈 多枝病変合併症例に打ける一般外科手術. 外科 $52: 1029-1033,1990$
9) Dalton ML, Parker TM, Mistrot JJ et al : Concomitant coronary artery bypass and noncardiac surgery. Thorac Cardiovasc Surg 75 : $621-624,1978$

10) Charles SR: Cardiac risk and its relevancea to the preoperative assessment. Surgery 34 : 2308-2310, 1991

11）鬼束憞義, 尾関 豊, 日野晃紹注：早期予後から 又た肝切除術100例の検討. 岐阜大医紀39： $453-460,1991$

12）日本肝癌研究会編：原発性肝癌取扱い規約. 金原 出版, 東京, 1992

\section{A Simultaneous Operative Case of Hepatocellular Carcinoma Combined with Ischemic Heart Disease}

Tatsumi Iida, Hideo Itoh, Yoshifumi Katagiri, Hironori Arakawa, Tomoyuki Miyata, Satoshi Sakai, Syoushi Senga, Masatomo Hayashi and Hajime Hirose First Department of Surgery, Gifu University School of Medicine

A case of simultaneous operation for hepatocellular cartinoma (HCC) and ischemic heart disease is reported. A 68-year-old man complained of abdominal pain. Examinations revealed a liver tumor in segment $6,30 \mathrm{~mm}$ in diameter, and also revealed coronary artery stenosis and obstruction. His liver function and other labolatory data were normal, and hepatectomy was recommended for HCC based on our data. His coronary artery disease was also suitable for bypass graftings, because of the good cardiac function. Coronary artery bypass grafting (CABG) and partial hepatectomy were performed simultaneously on March 17, 1992. The patient was discharged from our hospital uneventfully on the 21 st postoperative day. We conclude that simultaneous performance of hepatectomy and CABG is an effective therapeutic approach for HCC combined with ischemic heart disease.

Reprint requests: Tetsumi Iida First Department of Surgery, Gifu University School of Medicine 40 Tsukasamachi, Gifu, 500 JAPAN 